J. Bangladesh Acad. Sci., Vol. 42, No. 1, 99-104, 2018

\title{
COMPARATIVE STUDY OF THE PERFORMANCE OF SILICON SOLAR PANEL AT THREE DIFFERENT LOCATIONS OF BANGLADESH
}

\author{
MOHAMMAD ASADUL HAQUE* AND MD. TAKRIM ALAM RIFAT \\ Department of Physics, University of Chittagong, Chittagong, Bangladesh
}

\begin{abstract}
Solar cell is a device that converts photons into electricity. The performance of a solar cell depends on its efficiency. The efficiency of a solar cell depends on some atmospheric variables such as light intensity, temperature, pressure, wind, humidity, precipitation and the sky condition etc.. Geographical locations are the main factor for the variation of atmospheric variables. Due to atmospheric variables the solar cell efficiency is not same for all places of the World. Solar cell has been analyzed from different approach to improve its efficiency. The objective of this research is to analyze the efficiency of a silicon solar panel at three different places: Chittagong University Campus, Sandwip Island and Shibpur thana of Narshingdi district of Bangladesh. The efficiency mostly depends on the light intensity and temperature, however slightly depends on humidity. The experimental study shows that among the three places Norshingdi district is more suitable for solar power with the efficiency of $16.25 \%$ than other two places, where the efficiencies are $15.7 \%$ at Chittagong University Campus and $15.83 \%$ at Sandwip Island.
\end{abstract}

Key-words: Solar panel, Temperature, humidity, open-circuit voltage, short-circuit current, fill-factor and efficiency.

\section{INTRODUCTION}

Energy is a property of objects which can be transferred to other objects or converted into different forms. Energy is a basic human need and is an essential part of our daily lives. Due to the use of non-renewable energy the environmental pollution has reached such high levels that it becomes a serious threat to vegetation, wild life and human health. The major areas of environmental problems may be classified as follows: water pollution, greenhouse effect, hazardous air pollutants, maritime pollution, acid rain, stratospheric ozone depletion etc.

A solar cell is a device that converts photons from the sun into electricity. In the year
1980 research on silicon solar cell to increase their efficiency achieved the efficiency of 16\% (Haque et al., 2010). Solar cell has been analyzed from different approach to improve its efficiency. It is possible to obtain the cell efficiency theoretically by using: CrystallineSi (25-29)\%; GaAs (40-60)\%, GaSb (31$32) \%$; InGaAs (30-32)\%, InGaP (28-30)\%; Ga (20-22)\%; whereas achieved efficiencies are more less than that of the theoretical estimation (Haque et al., 2008).

Bangladesh is a developing country and is suffering from severe energy crises. In Bangladesh most of the power plants are gas and oil based. Now-a-days the state is trying

* Corresponding author: <asad.physics@cu.ac.bd>. 
to overcome the problem with costly rental power plants. Renewable energy especially photovoltaic system can partially solve this problem. The photovoltaic is one of the most interesting and friendly environmental technological solution for the electrification of remote consumer or entire area. In Bangladesh solar energy has been introduced in 1996; by this time solar energy is gaining popularity and contributing power to solve energy crisis. Infrastructure Development Company Limited (IDCOL) started solar home system (SHS) program using the innovative financial and technology packages in 2003; where in the year 2016, 3.5 million families are involved (Rahman, 2015).

The performance of a solar cell depends on its efficiency. The efficiency of a solar cell depends on some atmospheric variables such as temperature, pressure, wind, humidity, precipitation and the sky condition at a given time etc. Geographical location is the main factors for the variation of atmospheric variables. Due to atmospheric variables the solar cell efficiency is not same for all places in the world.

The objective of this research is to analyze the efficiency of a silicon solar panel in three different places such as: Chittagong University Campus, Sandwip island of Chittagong district and Shibpur thana of Narshingdi district of Bangladesh. In this study, the same solar panel has been assessed by measuring light intensity, temperature, humidity, open-circuit voltage and short circuit current at three different places.

\section{SOLAR ENERGY IN DETAILS}

Photovoltaic systems harness the sun's rays as a direct source of energy and convert it into electricity that can be used in homes. Not only does this result in big savings in home power bills over the year, it's also very eco-friendly, producing no waste products or harmful emissions. Fig. 1 shows the solar energy process in details (wikipedia, Gordon and Fahrenbruch, 2017):

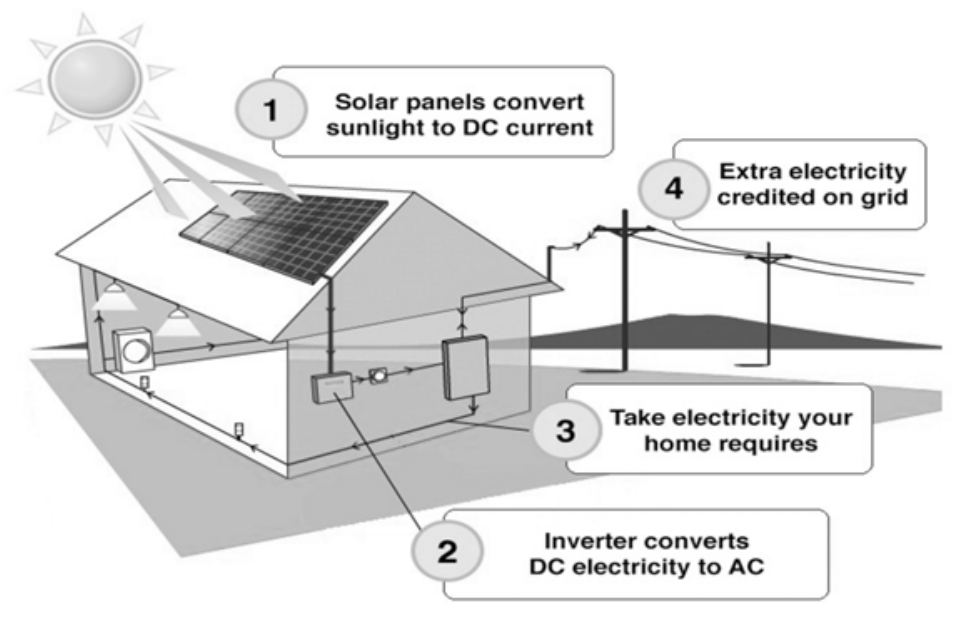

Fig.1 Image of a solar panel at home (Wikipedia, 2017) 
Step 1. Installation of PV Panels: Photovoltaic (PV) panels are placed on the roof. The panels should be north facing, or north-east or north-west facing, so that they are able to capture the most energy possible.

Step 2. Collection of Sun's Rays: The solar panels on the roof collect the sun's radiance during the day. They are made of silicon and only need the sun's radiance to work, so even on a cloudy day they will still generate power - albeit with lower production than on clear days.

Step 3. Conversion to DC Power (Panels): As the PV panels collect the sun's rays, they convert them into Direct Current (DC) electricity.

Step 4. Conversion to AC Power (Inverter): This DC power is then sent to an inverter which converts that DC power into Alternating current (AC) electricity.

Step 5. Power Is Sent Into the Home: The converted AC power is then fed into house wiring system, where it will power to lights, appliances, or anything else that uses electricity.

Step 6. Credit for unused electricity: If more power from the PV system is produced than it will serve the house requirements and the excess power is automatically fed back into the public grid, and one will be given a credit for that contributed electricity.

\section{METHODOLOGY, SITE SELECTION AND DATA COLLECTION}

Bangladesh is a developing country and crisis of power is the main constraints regarding that. Geographical location of Bangladesh is very much suitable for solar power. The performance of a solar cell depends on its efficiency where the efficiency varies on meteorological parameters such as: sunlight, temperature, humidity, day-time etc. For that reason the performance of a solar panel would be different in different places. In that regard, three different places of Bangladesh have been selected. These are such as (Wikipedia, 2017):

(i) Chittagong University campus $\left(22^{\circ} 46^{\prime} \mathrm{N}-\right.$ $\left.91^{\circ} 79^{\prime} \mathrm{E}\right)$

(ii) Sandwip island of a coastal area in Chittagong district $\left(22^{\circ} 29^{\prime} \mathrm{N}-91^{\circ} 26.5^{\prime} \mathrm{E}\right)$

(iii) Shibpur thana in Norshingdi district $\left(24^{\circ} 22^{\prime} \mathrm{N}-90^{\circ} 44.3^{\prime} \mathrm{E}\right)$

to collect the above mentioned data for analyzing the efficiency. The survey areas are shown in the map of Bangladesh in Fig. 2.

A silicon solar panel of size $(65 \mathrm{~cm} \times 65 \mathrm{~cm})$ has been setup in the open air on the roof-top of a building to get data directly.

Open-circuit voltage $\left(\mathrm{V}_{\mathrm{OC}}\right)$, Short-circuit current $\left(\mathrm{I}_{\mathrm{SC}}\right)$, are measured from the voltmeter and ammeter that are adjusted with the panel. Luminance meter and hydrometer have been used for the measurement of (light intensity $\mathrm{x} \quad 100$ lux) and (humidity \& temperature) respectively. All the data have been recorded from 9 am to $4: .30 \mathrm{pm}$ after every twenty minutes for fourteen days at a place at a stretch. The fill-factor (FF) of the silicon solar cell was fixed 0.88 . 


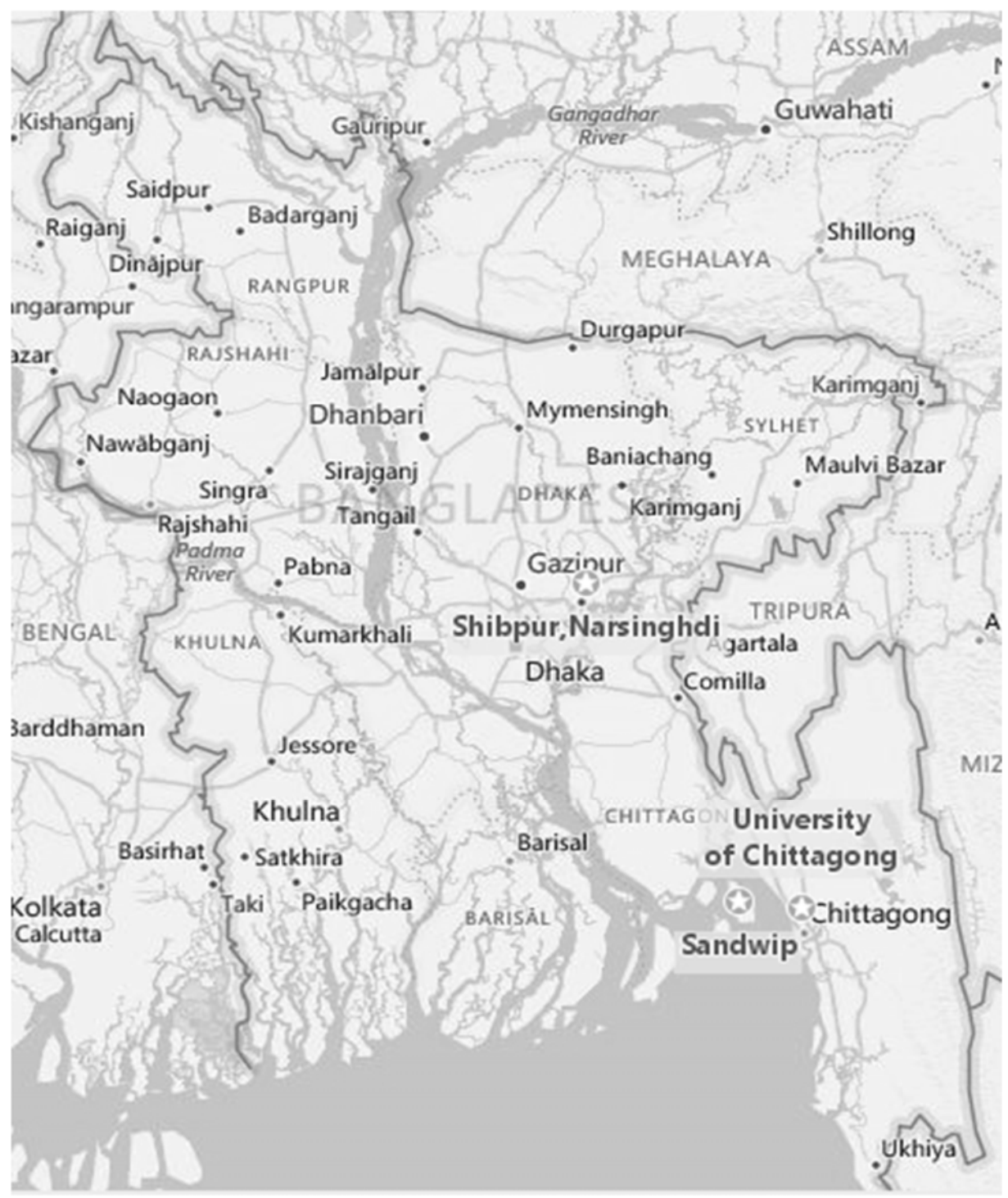

Fig. 2. Survey area shown in the map of Bangladesh.

\section{RESULTS AND DISCUSSION}

The collected data have been analyzed for efficiency by using the equation (Sze, 2009)

$$
\eta=\frac{V_{m p} I_{m p}}{P_{\text {in }}}=\frac{V_{O C} I_{S C} F F}{P_{\text {in }}}
$$

and presented through several graphs:
The above observations (Fig. 3.1-3.4) indicate that the efficiency mostly depends on the light intensity; temperature and slightly depends on humidity. The efficiency of a solar panel increases with increasing light intensity and temperature but decreases with the increasing humidity. Among the above 


\section{(i) Chittagong University Campus}
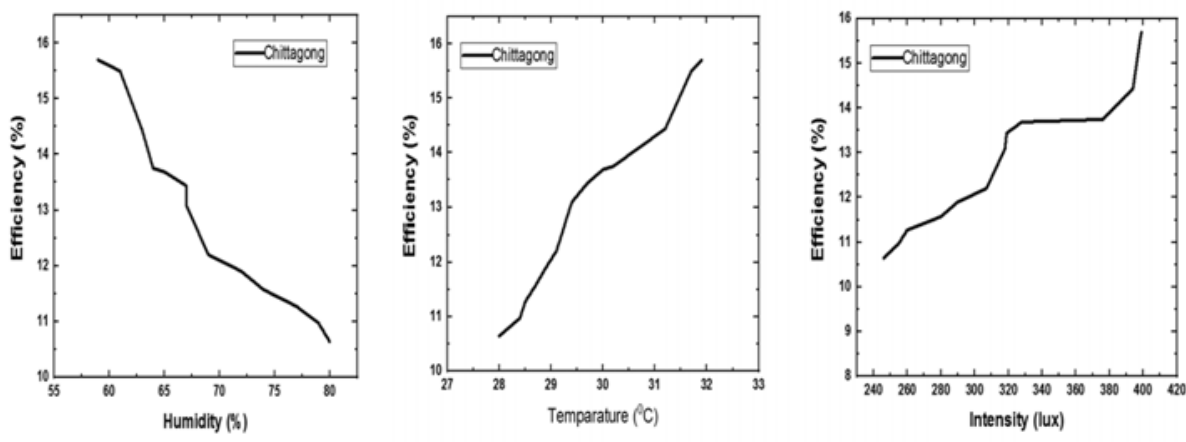

Fig. 3.1. Graphical representation efficiency versus humidity/temperature/Intensity respectively at Chittagong University Campus

(ii) Sandwip Island
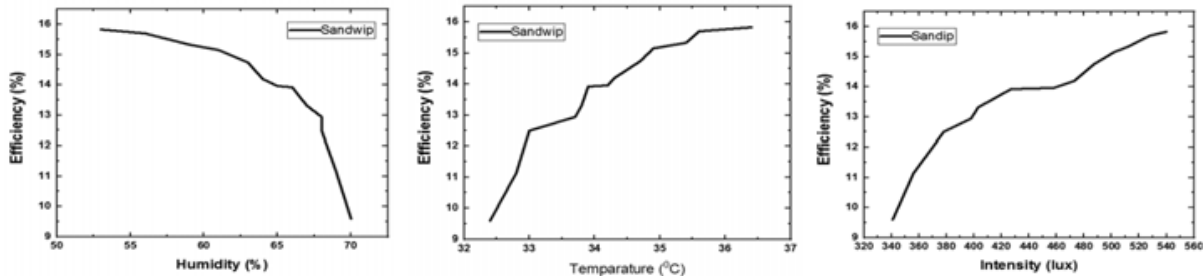

Fig. 3.2. Graphical representation of efficiency versus humidity/temperature/Intensity respectively at Sandwip Island

(iii) Shibpur thana of Narshingdi District
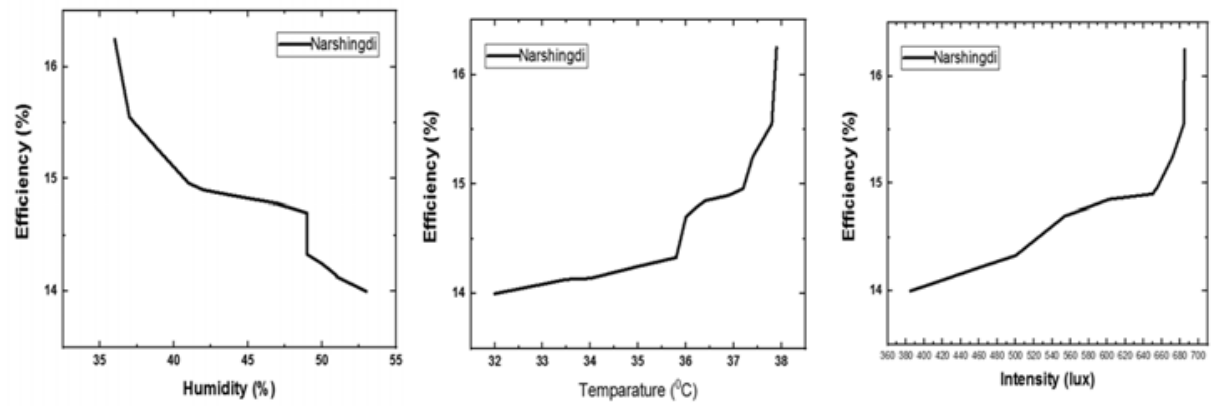

Fig. 3.3. Graphical representation of efficiency versus humidity/temperature/Intensity respectively at Narshingdi

three places Norshingdi district is more suitable for solar power with the efficiency of $16.25 \%$ than the other two places, where the efficiencies are $15.7 \%$ at Chittagong university campus and $15.83 \%$ at Sandwip. Though the light intensity and temperature is maximum at Sandwip but the efficiency is not upto that level due to humidity. Finally, it 


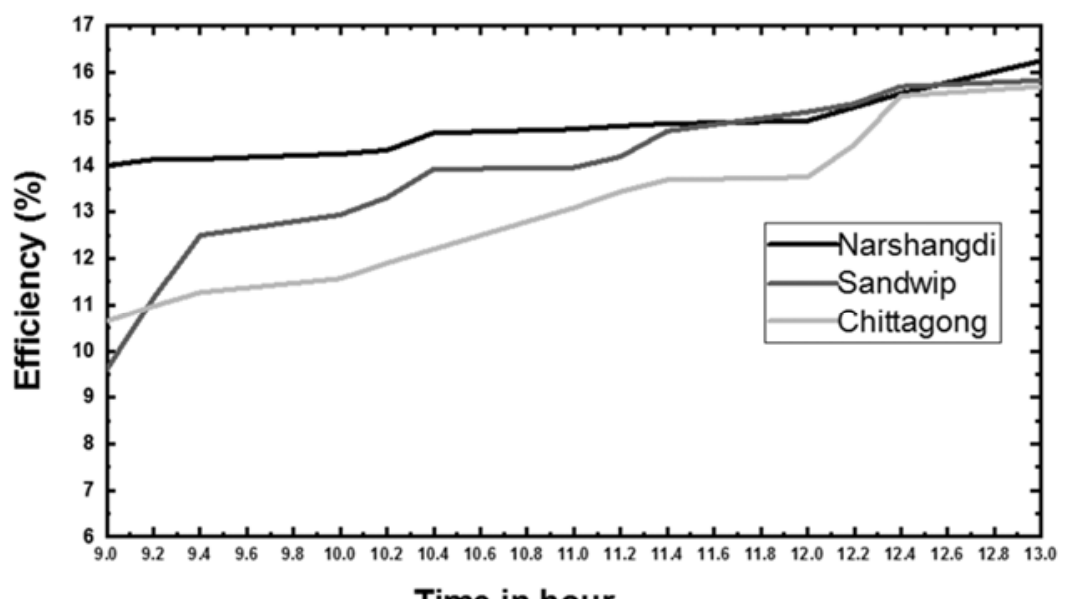

Time in hour

Fig. 3.4. Comparative graphical representation of time versus efficiency at three places

could be concluded that due to geographical location the western side is very much prospective for solar power then eastern side of Bangladesh.

\section{ACKNOWLEDGEMENT}

The authors are highly grateful to M. Mansur Ali, Developing Manager of Jevon Bhīma Corporation and Mr. Tajul Islam of Sandwip, Mohammad Musharraf Hossain, Chief Technician of Paratoli Solar power plant, Narshingdi, and Md. Mamunur Rashid and Tahmina Mina for their kind cooperation for this work.

\section{REFERENCES}

Fahrenbruch, A. L. and R. H. Bube. 1986. "Fundamentals of solar cell". "Photovoltaic solar cell conversion".

Gordon, J. 2005. "Solar energy- the state of the art", ISES paper, visited on NovemberDecember 2017.
Haque, M. A. and J. Rahman. 2010. "Power Crisis and solution in Bangladesh" Bangladesh Journal of Scientific and Industrial Research (BJSIR) 45 (2); 155-162.

Haque, M. A., M. A. Basith, Z. H. Mahmud, J. Rahman and M. Huq. 2008. "A study on the carrier recombination in the back surface for the performance of crystalline Si-solar cell" The Dhaka University Journal of Science, 56(2): 143-146.

Rahman, P. 2015. "Bangladesh aims to be World's first solar nation" Reuters by private communication.

Sze, S. 2009. "Physics of Semiconductor Devices" $3^{\text {rd }}$ edition $986-999$.

www. wikipedia.org/wiki/Solar cell visited on November-December 2017

www. wikipedia.org/wiki/University_of Chittagong, visited on November-December 2017.

www. wikipedia.org/wiki/Sandwip Upazila, visited on November-December 2017.

www. wikipedia.org/wiki/Shibpur_Upazila, visited on November-December 2017.

(Received revised manuscript on 13 May, 2018). 